\title{
PENGUKURAN KINERJA BANK UMUM SYARIAH DENGAN MAQASID INDEX DAN SHARIA CONFORMITY AND PROFITABILITY (SCNP)
}

\author{
Lia Anggraeni Prasetyowati \\ Program Studi Akuntansi Syariah \\ Sekolah Tinggi Ekonomi Islam SEBI \\ Email: prasetyowatilia@gmail.com
}

Luqman Hakim Handoko

Program Studi Perbankan Syariah

Sekolah Tinggi Ekonomi Islam SEBI

\begin{abstract}
This study aims to measure the performance of Islamic banking by using maqasid sharia Framework and SCnP model, which both of the models have been adapted to the characteristics of Islamic banking. Research carried out on seven Islamic Commercial Banks (BUS) for five years, from 2010 to 2014. The results by using maqasid index model shows that there are variations and fluctuative performance between BUS. The total of maqasid index over the past five years are in the range from 0,16901 to 0,34297. Bank Muamalat Indonesia is considered as the most stable BUS on maqasid sharia performance during the period of observation. This statement can be concluded from the BMI total index which always exceeds 0,30 and always got the first rank or second rank in each year, except in 2014, where in 2014 a decline of performance simultaneously happened on the 6 samples of BUS including BMI. Next, the performance measurement by using $\mathrm{SCnP}$ model, showed that during five years most of the BUS in Indonesia are at LRQ (Lower Right Quadrant) and LLQ (Lower Left Quadrant), it means that most of BUS in Indonesia have high sharia conformity but low profitability, or have low sharia conformity and low profitability. BMI decide as the best performance bank by Using SCnP model. It can be concluded as we know that $\mathrm{BMI}$ is the most consistent bank in URQ. Measurement using maqasid index and SCnP model show not only Islamic banks with highest total index can reach URQ. It can be concluded from BPS which two times get the first rank but BPS can not reach URQ.
\end{abstract}

Keywords: Islamic Commercial Bank, Islamic Banking Performance, Maqasid Index, SCnP Model, Sharia Conformity, Profitability.

\section{PENDAHULUAN}

Tahun 1992 merupakan kemunculan perbankan syariah pertama di Indonesia. Ditandai dengan berdirinya Bank Muamalat Indonesia (BMI). Meskipun baru terdapat satu bank syariah pada waktu itu, namun sistem perbankan syariah tidak kalah dengan perbankan konvensional. Hal ini terbukti ketika terjadi krisis moneter tahun 1997-1998, perbankan syariah - BMI- tidak mengalami spread off negatif. Hal itu merupakan sebuah prestasi, mengingat pada saat krisis terdapat 16 bank konvensional ditutup, 30 bank sudah dalam closing, 
dan 15 bank meminta waktu untuk diselamatkan (Ohio University Library, 1997). Semenjak saat itulah perbankan syariah Indonesia terus mengalami pertumbuhan pesat. Hingga akhir Desember 2014 terdapat 12 Bank Umum Syariah (BUS), 22 Unit Usaha Syariah (UUS), dan 163 Bank Perkreditan Rakyat Syariah (BPRS) yang tercatat di OJK. Selain itu menurut survei yang dilakukan oleh Ernst and Young (2015), Indonesia merpakan salah satu negara yang termasuk ke dalam kategori Rapid Growth Markets (RGMs) dan diprediksi akan menjadi salah satu negara dengan gelombang besar keuangan syariah berikutnya.

Namun di tengah berbagai capaian yang mengagumkan tersebut, ternyata masih banyak masyarakat Indonesia yang belum memahami konsep dan sistem perbankan syariah. Menurut Mu'allim (2003), hal ini disebabkan karena kurangnya pemahaman masyarakat mengenai perbankan syariah atau dengan kata lain terdapat asymetric information antara perbankan syariah dengan masyarakat. Hal serupa juga ditemukan dalam penelitian lain yang dilakukan oleh Hamidi, et.al (2006), Wulandari dan Subagio (2015), Usman (2015), dan Widigdo, Marimin, dan Fahmi (2016).

Dari hasil beberapa penelitian di atas, dapat diketahui bahwa pada umumnya masyarakat Indonesia tidak menyetujui adanya bunga, menyatakan bahwa bunga adalah termasuk ke dalam riba dan oleh sebab itu merupakan sesuatu yang haram, serta tingkat kepercayaan masyarakat Indonesia terhadap bank syariah relatif tinggi. Akan tetapi, sebagian besar masyarakat Indonesia juga relatif masih belum bisa membedakan bagaimana konsep dan praktik perbankan syariah, sehingga masih banyak pula yang menganggap bahwa bank syariah sama saja dengan bank konvesional dan pada akhirnya menganggap bahwa bagi hasil dari bank syariah sama saja dengan bunga dari bank konvensional.

Dengan berbagai permasalahan yang dihadapi oleh perbankan syariah tersebut, maka audit kepatuhan syariah menjadi sangat penting untuk dilakukan. Husein (2011) dalam Suhada dan Pramono (2014) mengusulkan prosedur audit kepatuhan syariah melalui lima pendekatan, yaitu pendekatan halal-haram, pendekatan akad, pendekatan dokumentasi hukum, pendekatan maqashid syariah, dan pendekatan laporan keuangan.

Lebih khusus mengenai audit kepatuhan syariah dengan pendekatan maqashid syariah para peneliti telah membuat indeks terkait pendekatan tersebut (Suhada \& Pramono, 2014). Indeks ini lebih dikenal dengan maqashid indeks. Dengan adanya maqashid indeks ini dapat dilihat bahwa sudah sejauh mana peran perbankan syariah dalam menciptakan kemaslahatan, sehingga dengan indeks ini pihak regulator (pemerintah) dapat mengontrol kegiatan perbankan syariah agar tidak hanya mengejar profit tetapi juga memperhatikan unsur kemaslahatan di dalamnya. Tidak hanya itu, melalui maqashid indeks ini masyarakat juga memiliki acuan untuk memutuskan di bank syariah mana mereka akan menempatkan dananya.

Oleh karena itu diperlukan sebuah alat analisis untuk mengetahui kinerja perbankan syariah di Indonesia terutama untuk menilai kinerja dari sudut pandang nilai-nilai syariah yang diterapkan dalam operasional 
perbankan syariah sehari-hari. Namun sampai saat ini pengukuran kinerja bank syariah biasanya dilakukan dengan menggunakan alat ukur bank konvensional, di antara alat ukur tersebut adalah metode FRA (Financial Ratio Analysis), metode EVA (Economic Value Added), analisis CAMELS (Capital, Assets, Management, Equity, Liability, Sensitivity), metode DEA (Data Envelope Analysis), dan lain sebagainya (Antonio, Sanrego, \& Taufiq, 2012). Padahal pengukuran kinerja perbankan syariah menggunakan metodemetode konvensional menunjukkan hasil yang kurang memuaskan dan menunjukkan kesan bahwa kinerja perbankan syariah masih jauh tertinggal dibandingkan bank konvensional (Kuppusamy, Saleh, \& Samudhram, 2010). Hal ini turut dibuktikan oleh banyak penelitian lain yang menunjukkan hasil serupa, beberapa diantaranya adalah penelitian yang dilakukan oleh Rosly dan Abu Bakar (2003), Moin (2008), Badreldin (2009), Majid, et.al (2013), dan Erol et.al (2014).

Sejatinya, penelitian mengenai alat ukur yang telah disesuaikan dengan karakteristik perbakan syariah telah ada. Beberapa peneliti telah berupaya untuk membuat alat ukur atau framework yang telah disesuaikan dengan konsep dan praktik perbankan syariah. Shahul Hameed et al. pada 2004 memperkenalkan Islamicity Performance Index, selanjutnya Mohammed, Djulzastri, dan Taib pada 2008 dengan Maqasid Index, dan Kuppusamy et.al pada 2010 dengan metode Sharia Conformity and Profitability (SCnP). Seluruh hasil penelitian yang menggunakan alat ukur tersebut menunjukkan hasil yang lebih baik jika dibandingkan dengan mengukur menggunakan metode konvesional. Oleh sebab itu, penelitian ini akan mengukur kinerja perbankan syariah menggunakan metode yang telah disesuaikan dengan perbankan syariah, yakni metode maqashid indeks dan model SCnP.

\section{TELAAH LITERATUR DANPERUMUSANHIPOTESIS}

\subsection{KONSEP MAQASHID SYARIAH}

Syariah Islam digunakan sebagai hukum untuk menjaga keselamatan dan untuk memperbaiki serta menyempurnakan kehidupan manusia. Hal ini dinyatakan dalam Al-Quran surat al-Anbiyaa ayat 107:

Artinya:"Dan tiadalah kami mengutus Engkau (Muhammad), melainkan untuk menjadi rahmat bagi seluruh alam semesta”. (Q.S. al-Anbiyaa [21]: 107).

Kemudian secara spesifik disebutkan di dalam surat Yunus ayat 57, syariah adalah sebagai penyembuh penyakit yang ada di dalam dada, serta petunjuk, dan rahmat bagi orang-orang yang beriman. Tujuan rahmat ini diwujudkan melalui perwujudan maslahah (manfaat). Para ulama sepakat bahwa perwujudan konsep maslahah ini disebut sebagai tujuan syariah atau maqashid syariah (Kamali, 2008). 
Secara bahasa maqashid berasal dari kata maqshid (jamak: maqashid), yang berarti tujuan, prinsip, atau akhir. Dengan demikian dapat diartikan bahwa maqashid syariah adalah tujuan-tujuan atau prinsip-prinsip disyariatkannya syariat Islam (Auda, 2008). Adapun tujuan diturunkannya syariah menurut Abu Zahrah ada tiga, yaitu:

1. Pendidikan bagi setiap individu (tahdzibul fardh/educating individual)

Adanya pendidikan bagi setiap individu ini bertujuan agar setiap muslim bisa menjadi sumber kebaikan, bukan malah menjadi sumber keburukan bagi masyarakat di lingkungannya. Hal ini dapat diwujudkan melalui berbagai ragam ibadah yang disyariatkan, yang semuanya dimaksudkan untuk kebersihan jiwa serta memperkokoh kesetiakawanan sosial. Ibadah-ibadah tersebut dapat membersihkan jiwa dari kotoran-kotoran (penyakit) yang melekat di hati manusia. Dengan demikian akan tercipta suasana saling mengasihi, bukan saling berbuat lalim dan keji di antara sesama muslim (Zahrah, 2011).

2. Menegakkan keadilan (iqamah al-'adalah/establishing justice)

Adil yang dimaksudkan disini adalah adil kepada semua pihak tanpa melihat perbedaan agama. Seorang muslim harus berlaku adil kepada sesama muslim maupun kepada non muslim (Zahrah, 2011). Hal ini dijelaskan di dalam Al-Quran surat Al-Mai'dah ayat 8 sebagai berikut:

Artinya: "Wahai orang-orang yang beriman, jadilah kamu sebagai penegak keadilan karena Allah (ketika) menjadi saksi dengan adil. Dan janganlah kebencianmu terhadap kepada suatu kaum, mendorong kamu untuk berlaku tidak adil. Berlaku adillah karena (adil) itu lebih dekat kepada takwa. Dan bertakwalah kepada Allah, sungguh Allah Mahateliti apa yang kamu kerjakan.” (Q.S. Al-Ma’idah[5]: 8).

Islam mengacu kepada keadilan sosial. Di dalam Islam setiap orang mempunyai kedudukan yang sama di hadapan undang-undang dan pengadilan. Tidak ada perbedaan antara orang kaya dengan orang miskin. selain itu Islam tidak mengenal stratafikasi sosial (kasta) dengan memberikan keistimewaan kepada strata tertentu. Hal ini dikarenakan di mata Allah semua manusia sama, berasal dari tanah liat yang tidak bisa dibeda-bedakan oleh perbedaan warna kulit atau jenis kebangsaannya. Oleh sebab itu semua manusia mempunyai status hukum yang sama di depan hukum Islam (Zahrah, 2011).

3. Maslahah (Public Interest)

Maslahah yang dimaksudkan oleh Islam adalah maslahah yang menyangkut kepentingan umum, bukan hanya untuk kepentingan segelintir orang (Zahrah, 2011). Maslahah ini mengacu kepada pemeliharaan terhadap lima hal, yaitu: agama (diin), jiwa (nafs), akal $(a q l)$, keturunan (nasl), dan harta (maal). 
Ketiga konsep maqashid syariah yang telah dipaparkan di atas itulah yang ditransformasikan menjadi suatu model untuk mengukur kinerja perbankan syariah. Hal ini disebabkan karena bank syariah memiliki sistem yang berbeda dengan bank konvensional. Perbedaan yang sifatnya mendasar inilah yang akan membedakan formulasi atau kreasi produk perbankan syariah termasuk pendekatan evaluasi kinerjanya (Antonio, Sanrego, \& Taufiq, 2012).

\subsection{KONSEP MAQASHID INDEKS}

Mohammed et. al. mengadaptasi konsep Sekaran untuk menyusun definisi operasional variabel maqashid syariah menjadi suatu alat ukur untuk mengukur kinerja perbankan syariah. Konsep Sekaran ini menjabarkan konsep/concept (C) atau objektif (O) menjadi suatu contoh perilaku yang dapat diamati. Untuk dapat mengukur sejauh mana pencapaian dari masingmasing objektif yang telah ditentukan, maka akan dapat terlihat melalui beberapa indikator/dimensi (D) yang sesuai dengan objektif yang telah ditentukan. Indikator atau dimensi ini akan lebih jelas terukur melalui elemen (E) yang akan mengukur langsung hal-hal yang menggambarkan dimensi dan objektif. Untuk lebih jelasnya, perhatikan gambar di bawah ini.

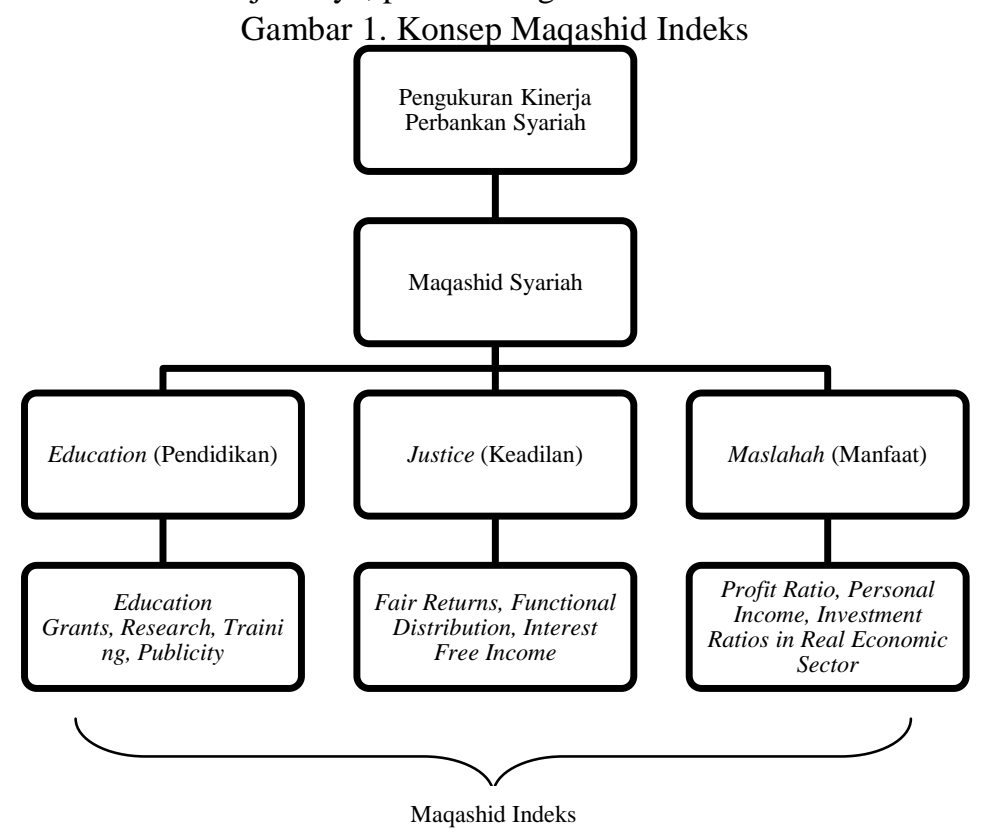

Sumber: Diadaptasi dari Mohammed, Razak, Taib, 2008 


\subsection{VERIFIKASI BOBOT MAQASHID INDEKS}

Agar kerangka maqashid syariah yang telah dijelaskan di atas dapat digunakan untuk mengukur kinerja perbankan syariah, Mohammed, Razak, dan Taib melakukan pembobotan untuk masing-masing objektif $(\mathrm{O})$ dan elemen (E). Verifikasi dilakukan dalam dua tahap. Tahap pertama dilakukan wawancara dengan dua belas ahli dari Timur Tengah dan Malaysia di bidang perbankan syariah, fiqh dan ekonomi Islam. Kemudian pada tahap kedua verifikasi bobot dilakukan dalam bentuk kuesioner. Pada tahap kedua ini, enam belas ahli diminta untuk menetapkan bobot dari setiap komponen dan untuk memastikan apakah pembobotan tersebut dapat diterima (acceptabble). Hasil rata-rata bobot yang diberikan oleh para ahli disajikan pada tabel di bawah ini:

Tabel 1. Bobot Rata-rata variabel Maqashid Indeks

\begin{tabular}{|c|c|c|c|}
\hline Objektif & $\begin{array}{l}\text { Bobot } \\
\text { Rata- } \\
\text { Rata } \\
\text { (dari 1) } \\
\end{array}$ & Elemen & $\begin{array}{l}\text { Bobot Rata- } \\
\text { rata (dari 1) }\end{array}$ \\
\hline \multirow{5}{*}{$\begin{array}{l}\text { 1.Education } \\
\text { (Tahdhib al- } \\
\text { Fardh) }\end{array}$} & \multirow{5}{*}{0.30} & $\begin{array}{l}\text { E1. Education } \\
\text { Grants/Donation }\end{array}$ & 0.24 \\
\hline & & E2. Research & 0.27 \\
\hline & & E3. Training & 0.26 \\
\hline & & E4. Publicity & 0.23 \\
\hline & & Total & 1 \\
\hline \multirow{4}{*}{$\begin{array}{l}\text { 2.Justice (Al- } \\
\text { 'adl) }\end{array}$} & \multirow{4}{*}{0.41} & E5. Fair Returns & 0.30 \\
\hline & & E6. Fair Price & 0.32 \\
\hline & & E7. Interest Free Product & 0.38 \\
\hline & & Total & 1 \\
\hline \multirow{3}{*}{$\begin{array}{l}\text { 3.Public Interest } \\
\text { (Al-Maslahah) }\end{array}$} & \multirow{3}{*}{0.29} & E8. Bank's Profit Ratio & 0.33 \\
\hline & & $\begin{array}{l}\text { E9. Personal Income } \\
\text { Transfers }\end{array}$ & 0.30 \\
\hline & & $\begin{array}{l}\text { E10. Investment Ratios in } \\
\text { Real Sector }\end{array}$ & 0.37 \\
\hline Total & 1 & Total & 1 \\
\hline
\end{tabular}

\subsection{KERANGKA KONSEPTUAL SHARIA CONFORMITY AND PROFITABILITY (SCNP)}

Model pengukuran kinerja yang diformulasikan oleh Kuppusamy, Saleh, dan Samudhram ini mengukur kinerja perbankan syariah melalui dua pendekatan (variabel), yakni variabel sharia conformity (kesesuaian syariah) dan variabel profitabilitas. Kuppusamy et. al. berpendapat bahwa pengukuran kinerja perbankan syariah haruslah menggunakan alat ukur yang menunjukkan sisi kesyariahan suatu bank syariah, namun tidak mengabaikan sisi konvensional -dalam hal ini profitabilitas-, hal ini dikarenakan bank syariah juga merupakan sebuah lembaga bisnis yang salah satu tujuan didirikannya adalah untuk mendapatkan keuntungan. 
Pada model SCnP, variabel syariah diukur dengan menghitung nilai rata-rata rasio kesesuaian syariah, sedangkan variabel konvensional diukur dengan menghitung rata-rata rasio profitabilitas. Variabel kesesuaian syariah, diukur dengan tiga rasio, yakni islamic investment ratio, islamic income ratio, dan profit sharing ratio. Sedangkan dari sudut pandang konvensional, juga diukur dengan tiga rasio, yakni ROA, ROE, dan PM.

Masing-masing dari rasio kesesuaian syariah dan rasio profitabilitas akan dirata-ratakan dan hasilnya akan dibentuk grafik empat kuadran dimana setiap kuadran dipisahkan dengan rata-rata rasio seluruh bank. Untuk lebih jelasnya perhatikan gambar di bawah ini.

Gambar 2. Model SCnP

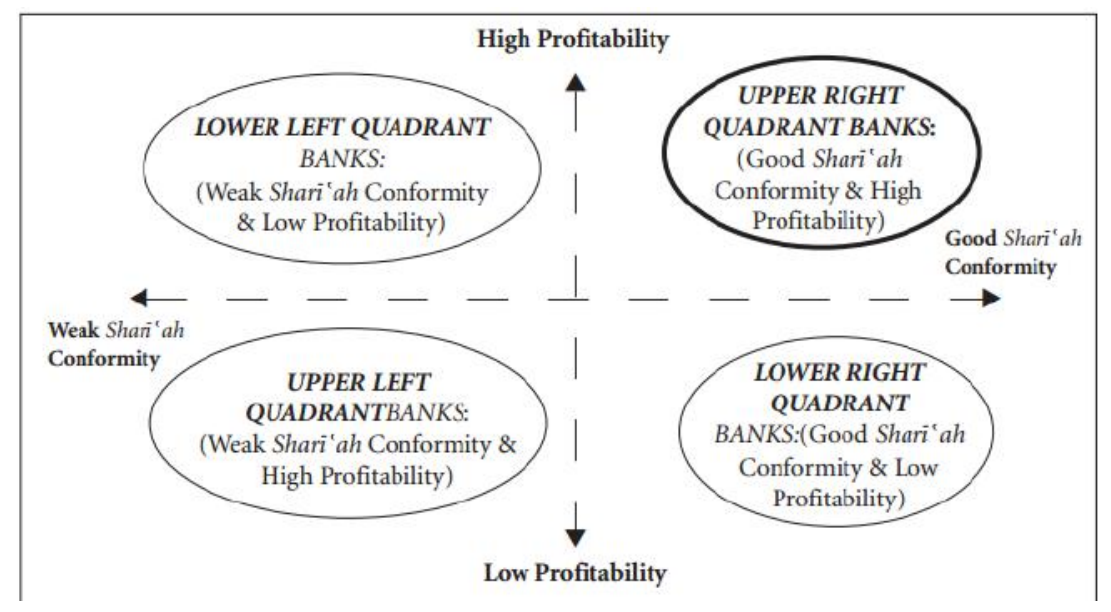

Sumber: Kuppusamy, Saleh, Samudhram, 2010

Grafik SCnP membagi grafik menjadi empat kuadran yakni, URQ (Upper Right Quadrant), LRQ (Lower Right Quadrant), ULQ (Upper Left Quadrant),dan LLQ (Lower Left Quadrant). Pojok kanan-URQ (Upper Right Quadrant) menunjukkan bank syariah yang memiliki tingkat kesesuaian syariah dan tingkat profitabilitas yang tinggi. Kuadran pojok kanan bawahLRQ (Lower Right Quadrant) menunjukkan bank syariah yang memiliki tingkat kesesuaian syariah yang tinggi tetapi memiliki tingkat profitabilitas yang rendah. Kuadran kiri atas-ULQ (Upper Left Quadrant) menunjukkan bank syariah yang memiliki tingkat kesesuaian syariah yang relatif rendah tetapi memiliki tingkat profitabilitas yang tinggi. Sementara itu kuadran pojok kiri bawah-LLQ (Lower Left Quadrant) menunjukkan bank syariah yang memiliki tingkat kesesuaian syariah dan tingkat profitabilitas yang lebih rendah.

\subsection{PENELITIAN TERDAHULU}

Pengukuran kinerja bank syariah dengan menggunakan alat ukur bank konvensional menunjukkan bahwa kinerja bank syariah tertinggal di 
belakang bank konvensional (Mohammed \& Taib, 2015). Oleh sebab itu beberapa peneliti berusaha untuk menciptakan suatu model untuk mengukur kinerja perbankan syariah yang lebih disesuaikan dengan karakteristik perbankan syariah

Tabel 2. Penelitian Terdahulu

\begin{tabular}{|c|c|c|c|c|}
\hline Nama & Judul & $\begin{array}{l}\text { Model dan } \\
\text { Metode }\end{array}$ & Sampel & Hasil \\
\hline $\begin{array}{l}\text { Shahul } \\
\text { Hameed, } \\
\text { et al. } \\
(2004)\end{array}$ & $\begin{array}{l}\text { Alternative } \\
\text { Dislosure } \\
\text { and } \\
\text { Performanc } \\
\text { Measures for } \\
\text { Islamic } \\
\text { Banks }\end{array}$ & $\begin{array}{l}\text { Perbanding } \\
\text { an } \\
\text { Islamicity } \\
\text { Disclosure } \\
\text { Index }\end{array}$ & $\begin{array}{l}\text { Bank } \\
\text { Islam Malay } \\
\text { sia Berhad } \\
\text { (BIMB) dan } \\
\text { Bahrain } \\
\text { Islamic Bank } \\
(\text { BIB) }\end{array}$ & $\begin{array}{l}\text { Bahrain Islamic } \\
\text { Bank (BIB) } \\
\text { lebih lengkap }\end{array}$ \\
\hline $\begin{array}{l}\text { Mohamme } \\
\text { d, Razak, } \\
\text { dan Taib } \\
(2008)\end{array}$ & $\begin{array}{l}\text { The } \\
\text { Performance } \\
\text { Measures of } \\
\text { Islamic } \\
\text { Banking } \\
\text { Based on the } \\
\text { Maqasid } \\
\text { Framework }\end{array}$ & $\begin{array}{l}\text { Maqashid } \\
\text { Indeks dan } \\
\text { SAW } \\
\text { (Simple } \\
\text { Additive } \\
\text { Weighting) }\end{array}$ & $\begin{array}{l}\text { Bank } \\
\text { Muamalat } \\
\text { Malaysia, } \\
\text { Islamic Bank } \\
\text { Bangladesh, } \\
\text { Bank } \\
\text { Syariah } \\
\text { Mandiri } \\
\text { Indonesia, } \\
\text { Bahrain } \\
\text { Islamic } \\
\text { Bank, } \\
\text { Islamic } \\
\text { International } \\
\text { Arab Bank } \\
\text { Jordan, } \\
\text { Sudanese } \\
\text { Islamic Bank }\end{array}$ & $\begin{array}{l}\text { JIIAB } \\
\text { menempati } \\
\text { peringkat } \\
\text { pertama }\end{array}$ \\
\hline $\begin{array}{l}\text { Mughess } \\
\text { Shaukat } \\
(2008)\end{array}$ & $\begin{array}{l}\text { The Recent } \\
\text { Financial } \\
\text { Growth of } \\
\text { Islamic } \\
\text { Banks and } \\
\text { Their } \\
\text { Fulfillment } \\
\text { of Maqasid } \\
\text { al-Shari'ah } \\
\text { (Gap } \\
\text { Analysis) }\end{array}$ & $\begin{array}{l}\text { Maqashid } \\
\text { Indeks, } \\
\text { SAW } \\
\text { (Simple } \\
\text { Additive } \\
\text { Weighting) } \\
\text {, dan Grid } \\
\text { Matrix }\end{array}$ & $\begin{array}{l}\text { Meezan } \\
\text { Bank } \\
\text { Pakistan, } \\
\text { Bank Islam } \\
\text { Malaysia, } \\
\text { Emirates } \\
\text { Bank UAE }\end{array}$ & $\begin{array}{l}\text { Meezan Bank } \\
\text { memperoleh } \\
\text { rating A, } \\
\text { Emirates Bank } \\
\text { memperoleh } \\
\text { rating B, dan } \\
\text { Bank Islam } \\
\text { Malaysia } \\
\text { memperoleh } \\
\text { rating C }\end{array}$ \\
\hline $\begin{array}{l}\text { Mustafa } \\
\text { Omar } \\
\text { Mohamme }\end{array}$ & $\begin{array}{l}\text { Developing } \\
\text { Islamic } \\
\text { Banking }\end{array}$ & $\begin{array}{l}\text { Maqasid } \\
\text { Index, } \\
\text { Mann }\end{array}$ & $\begin{array}{lr}12 & \text { Bank } \\
\text { Syariah dan } \\
12 & \text { Bank }\end{array}$ & $\begin{array}{lr}\text { Kinerja } & \text { Bank } \\
\text { Syariah } & \text { lebih } \\
\text { baik } & \text { diukur }\end{array}$ \\
\hline
\end{tabular}




\begin{tabular}{|c|c|c|c|c|}
\hline $\begin{array}{l}\text { d dan } \\
\text { Fauziah } \\
\text { Md Taib } \\
(2010)\end{array}$ & $\begin{array}{l}\text { Performance } \\
\text { Measures } \\
\text { Based On } \\
\text { Maqasid Al- } \\
\text { Shari'ah } \\
\text { Framework: } \\
\text { Cases of } 24 \\
\text { Selected } \\
\text { Banks } \\
\end{array}$ & $\begin{array}{l}\text { Whitney U } \\
\text { Test, dan } \\
\text { SAW } \\
\text { (Simple } \\
\text { Additive } \\
\text { Weighting) }\end{array}$ & $\begin{array}{l}\text { Konvensiona } \\
1 \\
2005)\end{array}$ & $\begin{array}{l}\text { dengan model } \\
\text { PMMS. Kinerja } \\
\text { bank } \\
\text { konvensional } \\
\text { lebih unggul } \\
\text { diukur dengan } \\
\text { model CBPM. }\end{array}$ \\
\hline $\begin{array}{l}\text { Kuppusam } \\
\text { y, Saleh, } \\
\text { dan } \\
\text { Samudhra } \\
\text { m (2010) }\end{array}$ & $\begin{array}{l}\text { Measurement } \\
\text { of Islamic } \\
\text { Banks } \\
\text { Performance } \\
\text { Using a } \\
\text { Shari'ah } \\
\text { Conformity } \\
\text { and } \\
\text { Profitability } \\
\text { Model }\end{array}$ & $\begin{array}{l}\text { Shari'ah } \\
\text { Conformity } \\
\text { and } \\
\text { Profitabilit } \\
\text { y Model } \\
(\mathrm{SCnP})\end{array}$ & $\begin{array}{l}\text { Bahrain } \\
\text { Islamic Bank } \\
\text { (BIB), } \\
\text { Kuwait } \\
\text { Finance } \\
\text { House } \\
\text { (KFH), } \\
\text { Jordan } \\
\text { Islamic Bank } \\
\text { for Finance } \\
\text { and } \\
\text { Investment } \\
\text { (JIBFI), dan } \\
\text { Bank Islam } \\
\text { Malaysia } \\
\text { (BIM) }\end{array}$ & $\begin{array}{lr}\begin{array}{l}\text { Secara } \\
\text { ketiga }\end{array} & \text { umum } \\
\text { syariah } & \text { yang } \\
\text { menjadi } & \text { sampel } \\
\text { sudah } & \\
\text { menunjukkan } \\
\text { perfroma yang } \\
\text { cukup } & \text { baik, } \\
\text { namun } & \text { BIM } \\
\text { berada } & \text { pada } \\
\text { kuadran } & \\
\text { terburuk } & \text { (LLQ) } \\
\text { selama } & \text { empat } \\
\text { tahun berturut- } \\
\text { turut. }\end{array}$ \\
\hline $\begin{array}{l}\text { Antonio, } \\
\text { Sanrego, } \\
\text { dan Taufiq } \\
(2012)\end{array}$ & $\begin{array}{l}\text { An Analysis } \\
\text { of Islamic } \\
\text { Banking } \\
\text { Performance: } \\
\text { Maqasid } \\
\text { Index } \\
\text { Implementati } \\
\text { on in } \\
\text { Indonesia } \\
\text { and Jordania }\end{array}$ & $\begin{array}{l}\text { Maqashid } \\
\text { Indeks, } \\
\text { SAW } \\
\text { (Simple } \\
\text { Additive } \\
\text { Weighting) }\end{array}$ & $\begin{array}{l}\text { Bank } \\
\text { Syariah } \\
\text { Mandiri, } \\
\text { Bank } \\
\text { Muamalat } \\
\text { Indonesia, } \\
\text { Jordan } \\
\text { Islamic } \\
\text { Bank, dan } \\
\text { Islamic } \\
\text { International } \\
\text { Arab Bank } \\
\text { Jordan } \\
\text { (IIABJ) }\end{array}$ & $\begin{array}{l}\text { Kinerja } \\
\text { perbankan } \\
\text { syariah di } \\
\text { Indonesia lebih } \\
\text { baik } \\
\text { dibandingkan } \\
\text { kinerja } \\
\text { perbankan } \\
\text { syariah } \\
\text { Jordan. }\end{array}$ \\
\hline $\begin{array}{l}\text { Widiya } \\
\text { Ratnaputri } \\
(2013)\end{array}$ & $\begin{array}{l}\text { The Analysis } \\
\text { of Islamic } \\
\text { Bank } \\
\text { Financial } \\
\text { Performance } \\
\text { By Using } \\
\text { CAMEL, }\end{array}$ & $\begin{array}{l}\text { Analisis } \\
\text { Rasio } \\
\text { CAMEL, } \\
\text { dan Shariah } \\
\text { Conformity } \\
\text { and } \\
\text { Profitabilit } \\
\end{array}$ & $\begin{array}{l}\text { Bank } \\
\text { Muamalat } \\
\text { Indonesia, } \\
\text { Bank } \\
\text { Syariah } \\
\text { Mandiri, } \\
\text { BCA } \\
\end{array}$ & $\begin{array}{lr}\text { Rasio } & \text { CAR, } \\
\text { RORA dan FDR } & \text { Felah memenuhi } \\
\text { telandar yang } & \text { stan } \\
\text { ditentukan BI, } & \text { sedangkan rasio } \\
\text { NPM dan } & \text { ROA } \\
\end{array}$ \\
\hline
\end{tabular}




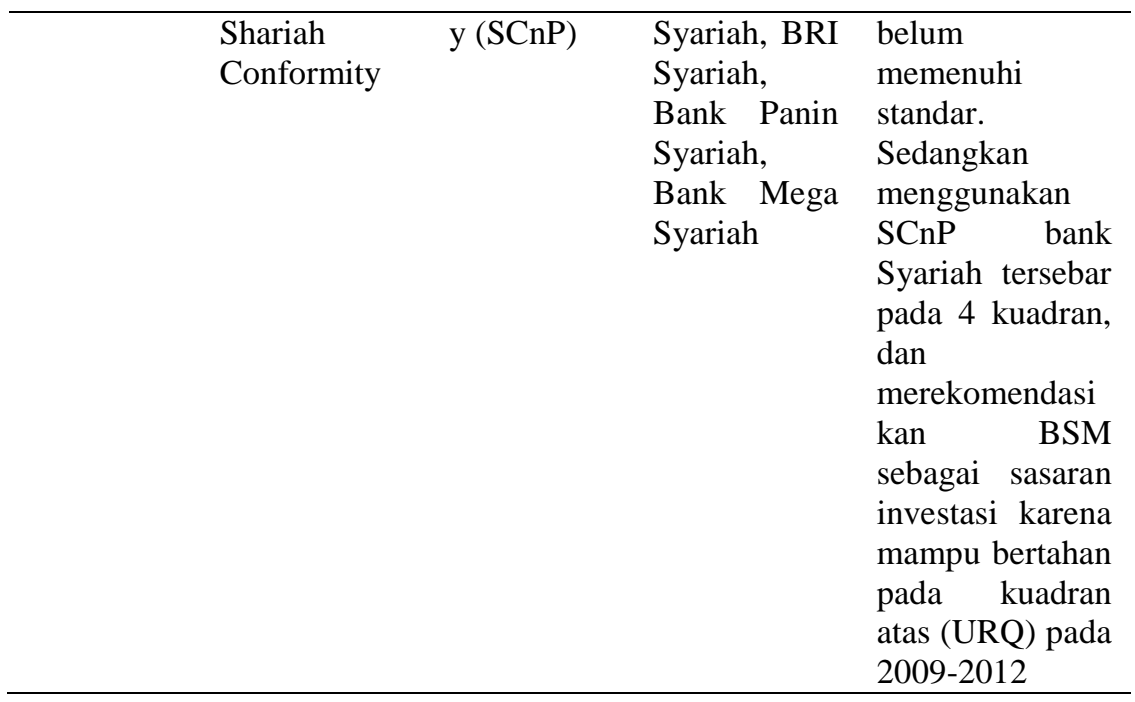

\section{METODE PENELITIAN}

Penelitian ini merupakan penelitian deskriptif kuantitatif dimana data yang digunakan adalah data sekunder yang diambil dari laporan tahunan Bank Umum Syariah (BUS) yang diseleksi menggunakan metode purposive sampling. Adapun kriteria yang digunakan untuk menyeleksi sampel pada penelitian ini, yakni: a. Sekurang-kurangnya telah beroperasi selama 5 tahun sampai dengan tahun 2014, b. Ketersediaan laporan keuangan tahun 20102014 di masing-masing website, c. Memiliki kelengkapan data untuk semua variabel untuk model maqashid indeks maupun SCnP. Dari hasil klasifikasi atas kriteria yang disebutkan di atas terdapat 7 BUS yang memenuhi semua kriteria tersebut, yaitu : Bank Muamalat Indonesia (BMI), Bank BRI Syariah (BRIS), Bank Syariah Mandiri (BSM), Bank Mega Syariah (BMS), Bank Panin Syariah (BPS), Bank Syariah Bukopin (BSB), dan Bank BCA Syariah (BCAS), masing-masing selama 5 tahun (periode) yakni dari tahun $2010-$ 2014. Adapun operasional variabel yang digunakan pada penelitian ini adalah sebagai berikut:

\subsection{OPERASIONAL VARIABEL}

Tabel 3. Operasional Variabel Maqashid Indeks

\begin{tabular}{|c|c|c|c|}
\hline $\begin{array}{c}\text { Konsep } \\
\text { (Objektif) }\end{array}$ & Dimensi & Elemen & Rasio \\
\hline \multirow[t]{2}{*}{$\begin{array}{l}\text { 1.Educating } \\
\text { Individual }\end{array}$} & \multirow[t]{2}{*}{$\begin{array}{l}\text { D1.Advancement } \\
\text { of knowledge }\end{array}$} & $\begin{array}{l}\text { E1. Education } \\
\text { Grant }\end{array}$ & $\begin{array}{l}\text { R1. Education Grant or } \\
\text { Scholarship/Total } \\
\text { Expenses }\end{array}$ \\
\hline & & E2. Research & Research \\
\hline
\end{tabular}




\begin{tabular}{|c|c|c|c|}
\hline & & & $\begin{array}{l}\text { Expense/Total } \\
\text { Expenses }\end{array}$ \\
\hline & \multirow{3}{*}{$\begin{array}{l}\text { D2. Instilling } \\
\text { new skills and } \\
\text { improvements }\end{array}$} & \multirow{3}{*}{ E3. Training } & R3. $\quad$ Training \\
\hline & & & Expense/Total \\
\hline & & & Expenses \\
\hline & \multicolumn{2}{|l|}{ D3. Creating } & R4. Publicity \\
\hline & $\begin{array}{l}\text { awareness of } \\
\text { slamic banking }\end{array}$ & E4. Publicity & $\begin{array}{l}\text { Expense/Total } \\
\text { Expenses }\end{array}$ \\
\hline \multirow{3}{*}{$\begin{array}{l}\text { 2.Establishing } \\
\text { Justice }\end{array}$} & D1. Fair returns & $\begin{array}{ll}\text { E1. } & \text { Fair } \\
\text { Returns } & \end{array}$ & $\begin{array}{l}\text { R1. Profit/Total } \\
\text { Income }\end{array}$ \\
\hline & $\begin{array}{l}\text { D2. } \\
\text { product } \\
\text { services }\end{array}$ & $\begin{array}{l}\text { E2. } \\
\text { Functional } \\
\text { Distribution }\end{array}$ & $\begin{array}{l}\text { R2. Mudarabah and } \\
\text { Musharakah } \\
\text { Modes/Total } \\
\text { Investment Modes }\end{array}$ \\
\hline & $\begin{array}{l}\text { D3. Elimination } \\
\text { of negative } \\
\text { elements that } \\
\text { breed injustices }\end{array}$ & $\begin{array}{l}\text { E3. Interest } \\
\text { Free Product }\end{array}$ & $\begin{array}{l}\text { R3. Interest Free } \\
\text { Income/Total Income }\end{array}$ \\
\hline \multirow{3}{*}{$\begin{array}{l}\text { 3.Public } \\
\text { Interest } \\
\text { (Maslahah) }\end{array}$} & $\begin{array}{l}\text { D1. Profitability } \\
\text { of bank }\end{array}$ & $\begin{array}{ll}\text { E1. Profit } \\
\text { Ratios }\end{array}$ & $\begin{array}{l}\text { R1. Net Income/Total } \\
\text { Assets }\end{array}$ \\
\hline & $\begin{array}{l}\text { D2. } \\
\text { Redistribution of } \\
\text { income and } \\
\text { wealth }\end{array}$ & $\begin{array}{l}\text { E2. Personal } \\
\text { Income }\end{array}$ & $\begin{array}{l}\text { R2. Zakah Paid/Net } \\
\text { Assets }\end{array}$ \\
\hline & $\begin{array}{l}\text { D3. Investment } \\
\text { in vital real } \\
\text { sector }\end{array}$ & $\begin{array}{l}\text { E3. } \\
\text { Investment } \\
\text { Ratios in Real } \\
\text { Sector }\end{array}$ & $\begin{array}{l}\text { R3. Investment in Real } \\
\text { Economic Sector/Total } \\
\text { Investment }\end{array}$ \\
\hline
\end{tabular}

Sumber: Mohammed, Razak, dan Taib (2008), Mohammed dan Taib (2015)

Tabel 4. Operasional Variabel Sharia Conformity and Profitability

\begin{tabular}{llllc}
\hline Nama Variabel & Variabel & Indikator & Skala \\
\hline \multirow{3}{*}{$\begin{array}{l}\text { Sharia } \\
\text { Conformity }\end{array}$} & $\begin{array}{l}\text { Islamic } \\
\text { investment }\end{array}$ & $\begin{array}{l}\text { R1. Islamic Investment/Islamic } \\
\text { Investment and non islamic } \\
\text { investment }\end{array}$ & Rasio \\
\cline { 2 - 5 } & $\begin{array}{l}\text { Islamic } \\
\text { income }\end{array}$ & $\begin{array}{l}\text { R2. Islamic Income/Islamic } \\
\text { Income+Non Islamic Income }\end{array}$ & Rasio \\
\cline { 2 - 5 } & Profit-Sharing & $\begin{array}{l}\text { R3. } \\
\text { Mudharabah+Musharakah/Total } \\
\text { Financing }\end{array}$ & Rasio \\
\cline { 2 - 5 } Profitability & ROA & R1=Net Income/Total Assets & Rasio \\
\cline { 2 - 5 } & ROE & $\begin{array}{l}\text { R2 Net Income/Shareholder's } \\
\text { Equity }\end{array}$ & Rasio \\
\cline { 2 - 5 } & NP3 & Operating Revenue & Income/Total & Rasio \\
\hline
\end{tabular}




\subsection{PENGOLAHAN DAN ANALISIS DATA}

\subsubsection{Pengolahan dan Analisis Data Model Maqashid Indeks}

Analisis data dengan model maqashid indeks tersebut adalah sebagai berikut:

1. Menghitung rasio yang terdapat pada model maqashid indeks (lihat tabel 3)

2. Menghitung Performance Index, dihitung dengan menggunakan metode Simple Additive Weighting (SAW), yaitu perkalian antara rasio dengan bobot (lihat tabel 1). Sehingga jika dinotasikan dalam bentuk rumus:

$$
\mathrm{PI}=w \times E \times R
$$

Rumusan ini akan diterapkan kepada masing-masing elemen dari ketiga konsep (objektif), sehingga jika diaplikasikan untuk maqashid indeks objektif pertama, maka rumusannya adalah sebagai berikut:

$$
\begin{aligned}
\mathrm{PI}(\mathrm{O} 1)= & \left(w_{1}^{1} \times E_{1}^{1} \times R_{1}^{1}\right)+\left(w_{1}^{1} \times E_{1}^{2} \times R_{1}^{2}\right)+\left(w_{1}^{1} \times\right. \\
& \left.E_{1}^{3} \times R_{1}^{3}\right)+\left(w_{1}^{1} \times E_{1}^{4} \times R_{1}^{4}\right)
\end{aligned}
$$

Atau jika disederhanakan

$$
\begin{gathered}
\mathrm{PI}(\mathrm{O} 1)=w_{1}^{1}\left\{\left(E_{1}^{1} \times R_{1}^{1}\right)+\left(E_{1}^{2} \times R_{1}^{2}\right)+\left(E_{1}^{3} \times R_{1}^{3}\right)+\right. \\
\left.\left.E_{1}^{4} \times R_{1}^{4}\right)\right\}
\end{gathered}
$$

Dimana:

$\mathrm{PI}(\mathrm{O} 1)$ : performance index objektif pertama, yakni tahdhib al-fard (education) lihat tabel 3.1

$w_{1}^{1}$ : bobot dari objektif petama (lihat tabel 2.1)

$E_{1}^{1}$ : bobot untuk elemen pertama dari objektif pertama (lihat tabel 2.1)

$E_{1}^{2}$ : bobot untuk elemen kedua dari objektif pertama

$E_{1}^{3}$ : bobot untuk elemen ketiga dari objektif pertama

$E_{1}^{4}$ : bobot untuk elemen keempat dari objektif pertama

$R_{1}^{1}$ : penilaian untuk rasio pertama sesuai elemen pertama dari objektif pertama

$R_{1}^{2}$ : penilaian untuk rasio kedua sesuai elemen kedua dari objektif pertama

$R_{1}^{3}$ : penilaian untuk rasio ketiga sesuai elemen ketiga dari objektif pertama

$R_{1}^{4}$ : penilaian untuk rasio keempat sesuai elemen keempat dari objektif pertama

Maka, jika dinotasikan untuk perhitungan performance index objektif kedua dan ketiga adalah: 


$$
\begin{array}{r}
\mathrm{PI}(\mathrm{O} 2)=w_{2}^{2}\left\{\left(E_{2}^{1} \times R_{2}^{1}\right)+\left(E_{2}^{2} \times R_{2}^{2}\right)+\left(E_{2}^{3} \times R_{2}^{3}\right)\right\} \\
\mathrm{PI}(\mathrm{O} 3)=w_{3}^{3}\left\{\left(E_{3}^{1} \times R_{3}^{1}\right)+\left(E_{3}^{2} \times R_{3}^{2}\right)+\left(E_{3}^{3} \times R_{3}^{3}\right)\right\}
\end{array}
$$

Penjelasan masing-masing kode di atas sebagaimana penjelasan untuk kode performance index pertama, yakni dengan mengganti urutan nomor objektifnya.

3. Menjumlahkan hasil perhitungan seluruh maqashid indeks, yang dilambangkan sebagai berikut:

$$
\mathrm{MI}=\mathrm{PI}(\mathrm{O} 1)+\mathrm{PI}(\mathrm{O} 2)+\mathrm{PI}(\mathrm{O} 3)
$$

4. Memeringkat sesuai total maqashid indeks berdasarkan total MI tertinggi sampai terkecil

\subsubsection{Pengolahan dan Analisis Data Pendekatan SCNP}

Pengukuran kinerja keuangan BUS berdasarkan model SCnP yang dijabarkan dalam tahap-tahap berikut:

1. Menghitung rasio-rasio yang terdapat dalam variabel $\mathrm{SCnP}$ (lihat tabel 4).

2. Menghitung rata-rata dari setiap variabel, dengan rumus sebagai berikut:

$$
\begin{aligned}
& \bar{X} \mathrm{SC}=\frac{\mathrm{R} 1+\mathrm{R} 2+\mathrm{R} 3}{3} \\
& \overline{\mathrm{Dan}} \\
& \bar{X} \mathrm{P}=\frac{\mathrm{R} 1+\mathrm{R} 2+\mathrm{R} 3}{3}
\end{aligned}
$$

Dimana:

$\bar{X}$ SC: Rata-rata rasio variabel sharia conformity

$\bar{X}_{\mathrm{p}}$ : Rata-rata rasio 1, 2, dan 3 dari variabel profitability

R1 : Rasio pertama dari variabel Sharia Conformity atau Profitability

R2 : Rasio kedua dari variabel Sharia Conformity atau Profitability

R3 : Rasio ketiga dari variabel Sharia Conformity atau Profitability

Rata-rata $\overline{\mathrm{X}}_{\mathrm{SC}}$ akan dijadikan sebagai titik pada kordinat $\mathrm{X}$ (sharia conformity) dan rata-rata $\bar{X}$ p akan dijadikan sebagai titik pada kordinat Y (profitability).

3. Membuat Grafik SCnP dan mengintepretasi sesuai teori.

4. Membandingkan peringkat maqashid indeks dengan kuadran posisi grafik SCnP. 


\section{HASIL DAN PEMBAHASAN}

\subsection{KINERJA BANK UMUM SYARIAH BERDASARKAN PENDEKATAN MAQASHID}

INDEKS TAHUN 2010-2014

Berikut ini merupakan tabel hasil pengolahan data terhadap 7 BUS menggunakan metode Maqashid Indeks.

Tabel 5. Total MI Bank Umum Syariah Tahun 2010-2014

\begin{tabular}{|l|c|l|c|l|l|l|l|l|l|l|}
\hline \multirow{2}{*}{ Bank } & \multicolumn{2}{|c|}{2010} & \multicolumn{2}{c|}{2011} & \multicolumn{2}{c|}{2012} & \multicolumn{2}{c|}{2013} & \multicolumn{2}{c|}{2014} \\
\cline { 2 - 9 } & \multicolumn{1}{|c|}{ MI } & Peringkat & \multicolumn{1}{c|}{ MI } & Peringkat & MI & Peringkat & MI & Peringkat & MI & Peringkat \\
\hline BMI & 0.31779 & 1 & 0.30953 & 2 & 0.32008 & 2 & 0.34031 & 1 & 0.29403 & 3 \\
\hline BRIS & 0.27971 & 4 & 0.27337 & 5 & 0.22925 & 7 & 0.30017 & 4 & 0.27701 & 5 \\
\hline BSM & 0.31354 & 2 & 0.30526 & 3 & 0.31340 & 3 & 0.29351 & 6 & 0.26226 & 6 \\
\hline BMS & 0.25405 & 5 & 0.25242 & 7 & 0.27234 & 6 & 0.26401 & 7 & 0.24809 & 7 \\
\hline BPS & 0.16901 & 7 & 0.31018 & 1 & 0.34297 & 1 & 0.29693 & 5 & 0.29862 & 1 \\
\hline BSB & 0.29586 & 3 & 0.29175 & 4 & 0.29860 & 4 & 0.30068 & 3 & 0.29109 & 4 \\
\hline BCAS & 0.19384 & 6 & 0.25883 & 6 & 0.28142 & 5 & 0.30192 & 2 & 0.29806 & 2 \\
\hline
\end{tabular}

Dilihat dari tabel 5, dapat diketahui bahwa setiap BUS menunjukkan fluktuasi kinerja yang berbeda-beda setiap tahunnya. Dari total nilai MI selama kurun waktu lima tahun, dapat diketahui bahwa BMI adalah bank yang kinerja maqashid syariahnya terbaik di antara semua bank syariah lain, sebab BMI selalu memperoleh total nilai indeks tertinggi pertama atau kedua selama empat tahun berturut-turut (2010-2013). Adapun BMS dan BSB merupakan dua bank syariah yang kinerjanya paling stabil akan tetapi indeks maqashid syariahnya masih terbilang lebih rendah dibandingkan dengan bank syariah lain. Sedangkan BRIS, BSM, BCAS, dan BPS menunjukkan kinerja yang cukup fluktuatif selama lima tahun terakhir, hal ini bisa dilihat dari kenaikan dan penurunan total MI yang signifikan setiap tahunnya.

Penemuan yang cukup menarik terjadi pada BMI, sebab penurunan terbesar pada total MI di tahun 2014 terjadi pada BMI. Hal ini mengindikasikan bahwa BMI mengalami penurunan kinerja yang paling parah di antara seluruh bank syariah sampel. Tentunya hal ini merupakan suatu temuan yang sangat mengejutkan, pasalnya BMI adalah bank syariah pertama di Indonesia dan selalu menunjukkan kinerja terbaik selama empat tahun berturut-turut.

Penurunan kinerja maqashid syariah yang paling parah pada BMI di tahun 2014 ini disebabkan karena penurunan pada seluruh Performance Index (PI) dari objektif satu sampai dengan objektif ketiga. Berikut ini disajikan perbandingan PI pada BMI di tahun 2013 dan 2014.

Tabel 6. Penurunan Performance Index BMI di Tahun 2014

\begin{tabular}{|l|c|c|c|}
\hline \multicolumn{1}{|c|}{ BMI } & $\mathbf{2 0 1 3}$ & $\mathbf{2 0 1 4}$ & Penurunan \\
\hline PI (O1) & 0.00410 & 0.00294 & $(0.00116)$ \\
\hline PI (O2) & 0.24202 & 0.21119 & $(0.03083)$ \\
\hline PI (O3) & 0.09419 & 0.07990 & $(0.01430)$ \\
\hline Total MI & 0.34031 & 0.29403 & $(0.04628)$ \\
\hline
\end{tabular}

Sumber: Data Diolah 
Penurunan pada Performance Index objektif pertama (educating individual), lebih banyak disebabkan karena menurunnya beban pendidikan dan pelatihan di tahun 2014. Penurunan pada beban pendidikan dan pelatihan ini menyebabkan penurunan rasio pendidikan $\left(R_{1}^{1}\right)$ dan rasio pelatihan $\left(R_{1}^{3}\right)$ dari masing-masing sebesar $1,05 \%$ menjadi hanya $0,34 \%$ dari total beban, atau dengan kata lain terjadi penurunan sebesar dua pertiga proporsi beban pendidikan dan pelatihan tahun 2013. Adanya penurunan rasio $R_{1}^{1}$ (education grant) dan $R_{1}^{3}$ (training expense) ini mengakibatkan turunnya nilai indeks education expense dari 0,00075 menjadi 0,00025 dan indeks training expense dari 0,00082 menjadi 0,00027 .

Dalam konsep maqashid syariah, pengeluaran dana untuk keperluan pendidikan dan pelatihan ini termasuk ke dalam kategori hifzhul aql (penjagaan akal). Pendidikan pada bank syariah dinilai sangat penting mengingat bank syariah merupakan bank yang memiliki konsep yang berbeda dengan perbankan konvensional. Selain harus tunduk kepada regulasi pemerintah, bank syariah juga memiliki tanggung jawab yang lebih besar untuk tunduk kepada prinsip hukum syariah sebagai bentuk pertanggungjawaban kepada Allah.

Sebagaimana kegiatan perbankan pada umumnya, kegiatan usaha pada dunia perbankan syariah juga merupakan kegiatan yang membutuhkan kemampuan dan kompetensi tinggi, serta adaptasi terhadap perubahan yang sangat dinamis dari waktu ke waktu. Oleh sebab itu untuk mengelola bisnis perbankan syariah dibutuhkan karyawan yang memiliki tingkat pendidikan dan kompetensi yang mumpuni, serta akhlak yang baik. Bahkan tidak jarang, diperlukan keahlian khusus yang sangat spesifik dan teknikal untuk mengelola bisnis perbankan. Salah satu cara yang dapat dilakukan oleh bank syariah untuk dapat mewujudkan semua hal itu adalah dengan mengadakan kegiatan-kegiatan pendidikan dan pelatihan bagi karyawan.

Tingkat keseriusan suatu bank dalam mengadakan kegiatan sifatnya mendidik dan melatih karyawan dapat dinilai dari seberapa stabil rasio beban pendidikan dan pelatihan di setiap tahunnya. Apalagi mengingat bahwa kompetensi dan skill yang baik merupakan suatu kemampuan yang diperoleh karena diasah dengan cara terbiasa melakukan secara kontinyu. Maka sudah sewajarnya jika setiap bank syariah mempertahankan proporsi beban pendidikan dan pelatihan dalam jumlah yang wajar atau tidak terlalu besar selisihnya antar satu tahun ke tahun lainnya. Terlebih BMI yang merupakan bank syariah pertama berdiri di Indonesia, yang menjadi role model bagi bank syariah lain seharusnya lebih bisa menjaga stabilitas kedua rasio ini.

Adapun penurunan pada Performance Index kedua (establishing justice) adalah kontributor terbesar tehadap penurunan total MI BMI di tahun 2014. Penurunan Performance Index kedua ini disebabkan karena penurunan yang sangat signifikan pada dimensi fair returns yang diproksikan dengan net income on sales terhadap total income on sales.

Dari hasil perhitungan diketahui bahwa rasio pada dimensi fair returns BMI adalah sebesar 27,15\% di tahun 2013, menurun drastis menjadi hanya $6,79 \%$ di tahun 2014 . Sehingga dapat disimpulkan bahwa penurunan 
rasio pada dimensi fair returns ini disebabkan karena menurunnya pendapatan utama bank dari bagi hasil. Selain itu menurunnya pendapatan fee based income juga ikut andil dalam penurunan rasio pada dimensi fair returns. Sehingga apabila kedua jenis pendapatan tersebut dijumlahkan pada masing-masing tahun, dapat dihitung bahwa terdapat penurunan pendapatan operasional sebesar $17 \%$ dari tahun 2013. Penurunan rasio $R_{2}^{1}$ ini mengakibatkan menurunnya indeks pada dimensi fair returns dari 0,03340 menjadi 0,00836 .

Dimensi fair returns atau pengembalian yang adil ini dihitung berdasarkan laba operasional terhadap total pendapatan operasional. Rasio pada dimensi fair return yang positif ini menunjukkan bahwa bank syariah menikmati pengembalian atau kesejahteraan yang baik. Hal ini merupakan suatu bentuk keadilan untuk bank syariah, sebab bank syariah telah memberikan jasanya sebagai lembaga intermediari, mengeluarkan beban di awal, serta ikut menanggung risiko. Oleh karenanya return atau keuntungan merupakan suatu bentuk keadilan bagi bank syariah. Dalam koridor maqashid syariah, hal ini termasuk ke dalam hal menjaga harta (hifzhul maal) dan menjaga jiwa (hifzhun nafs). Jika bank syariah mampu untuk terus mendapatkan keuntungan, maka bank syariah juga akan mampu untuk terus ada dan memberikan manfaat ekonomi bagi masyarakat yang lebih luas. Menurunnya dimensi fair returns secara drastis pada BMI ini menunjukkan bahwa tingkat pengembalian yang adil pada BMI ini berkurang nilainya dibandingkan dengan tahun sebelumnya. Kenaikan dan penurunan dalam hal penerimaan keuntungan adalah hal yang wajar terjadi di dalam dunia bisnis, sehingga juga merupakan hal yang wajar jika BMI mengalami penurunan terlebih penurunan ini juga terjadi pada enam sampel bank syariah lain. Namun seharusnya, sebagai bank syariah yang menjadi role model keadaan ini tidak berlangsung lama hingga ke depannya. Sehingga diharapkan BMI dapat mengembalikan kondisi fair returns ini di masa mendatang.

Pembahasan selanjutnya adalah mengenai penurunan pada Perfomance Index objektif ketiga (public interest atau maslahah). Penurunan pada Performance Index objektif ketiga ini terjadi karena adanya penurunan yang sangat signifikan pada dimensi profitability of bank yang diproksikan dengan rasio net income terhadap total assets dan penurunan dimensi investment in vital real sector yang diproksikan dengan rasio investment in real economic sector terhadap total investment. Penurunan rasio pada dimensi profitability of bank ini disebabkan karena penurunan yang sangat signifikan pada laba bersih bank sebesar $65,38 \%$ di tahun 2014. Perlu diketahui bahwa penurunan pada rasio ini merupakan yang terburuk sepanjang tahun pengamatan (2010-2014).

Penurunan pada nilai indeks profitability of bank ini berbanding lurus dengan penurunan pada dimensi fair returns, sebab kedua dimensi ini samasama menghitung kinerja dari rasio laba. Sehingga jika rasio profit on sales terhadap total income on sales menurun, maka kemungkinan besar rasio net income terhadap total assets juga akan turut mengalami penurunan. Letak perbedaan kedua rasio ini adalah jika pada dimensi fair returns menghitung 
kinerja bank syariah dari perolehan laba operasi terhadap pendapatan operasi, sedangkan untuk dimensi profitability of bank diperoleh dari perhitungan laba bersih terhadap total aset. Pada kasus ini, dimensi fair returns BMI menurun, dengan demikian menyebabkan rasio profitability of bank juga ikut menurun, sehingga pada akhirnya kedua rasio ini memberikan kontribusi yang cukup besar pada penurunan kinerja maqashid indeks BMI di tahun 2014.

Selain disebabkan karena menurunnya rasio net income terhadap total assets, penurunan performance index objektif ketiga juga disebabkan karena menurunnya rasio investment in real economic sector secara signifikan. Dari hasil perhitungan, diketahui bahwa rasio investasi di sektor riil pada BMI adalah sebesar $86,76 \%$ di tahun 2013. Rasio tersebut menurun menjadi hanya sebesar 73,92\% di tahun 2014. Penurunan rasio investasi di sektor riil sebesar $12,84 \%$ ini disebabkan karena peningkatan yang signifikan pada investasi di sektor non riil. Adapun investasi pada sektor non riil yang mengalami peningkatan adalah, giro dan penempatan pada Bank Indonesia, giro pada bank lain, penempatan pada bank lain, dan investasi pada surat berharga. Sementara investasi pada sektor non riil mengalami peningkatan, di sisi lain investasi pada sektor riil mengalami penurunan, khususnya pada pembiayaan dengan akad istishna, qardh, dan mudharabah.

Secara umum dalam framework maqashid syariah, profitabilitas dapat digolongkan sebagai penjagaan harta (hifzul maal). Tidak hanya itu, jika bank syariah berhasil membukukan profitabilitas yang tinggi, maka bank syariah akan lebih banyak memberikan manfaat kepada masyarakat melalui distribusi dana zakat dari bank syariah kepada delapan golongan yang telah disebutkan dalam Al-Quran surat At-Taubah ayat 60. Sedangkan investasi pada sektor riil merupakan cerminan dari ciri khas utama bank syariah, yakni mendasarkan pembiayaan yang berdasarkan prinsip bagi hasil (profit and loss sharing). Investasi pada sektor riil mencerminkan keikusertaan bank syariah dalam pengembangan sektor riil di Indonesia. Investasi pada sektor riil pada gilirannya akan meningkatkan produksi di dalam negeri yang berujung pada membaiknya pertumbuhan ekonomi. Pertumbuhan ini terjadi karena uang tidak hanya beredar pada sektor keuangan saja, akan tetapi langsung menyentuh sendi-sendi perekonomian rakyat.Yang mana sektor riil ini adalah penopang utama perokonomian Indonesia. Dengan demikian, diharapkan di masa depan, BMI kembali meningkatkan pembiayaan di sektor riil atau kembali memberikan pembiayaan di sektor riil dengan jumlah minimal setara setara seperti tahun-tahun sebelumnya agar kembali memberikan maslahah yang tinggi kepada masyarakat.

Namun di tengah penurunan kinerja terparah sepanjang masa pengamatan, BMI layak untuk mendapat apresiasi. Pasalnya di tengah keterpurukan kinerja yang dialami, BMI mampu untuk konsisten membayarkan zakat perusahaan dan karyawan bahkan dalam jumlah yang meningkat di tahun 2014. Di tahun 2013 terdapat peningkatan pembayaran zakat sebesar 72,36\%. Dari penjelasan ini dapat diketahui bahwa BMI tetap berusaha untuk memberikan maslahah kepada sekitarnya melalui pemerataan 
pendapatan dengan tetap meningkatkan pembayaran zakat meskipun sedang dalam kondisi kinerja yang menurun paling buruk sekalipun.

Penyaluran zakat merupakan salah satu bentuk perwujudan keadilan dari pihak yang mempunyai kelebihan harta kepada orang-orang yang berhak, sebab di dalam harta yang dimiliki oleh seseorang terdapat hak-hak orang lain yang mesti dikeluarkan. Seseorang atau perusahaan yang menjalankan usaha kemudian mendapatkan keuntungan yang melebihi nishab dari hasil usahanya, wajib untuk mengeluarkan zakat.

Penyaluran zakat kepada yang berhak ini juga merupakan salah satu upaya untuk mencegah kesenjangan sosial antara kaya dengan miskin. Dengan adanya penyaluran zakat, maka bank syariah telah turut dalam usaha menjaga seluruh unsur maqashid syariah, yakni menjaga agama (diin), jiwa (nafs), akal (aql), keturunan (nasl), dan harta (maal). Menjaga agama, karena membayar zakat merupakan perintah agama. Menjaga jiwa, sebab dengan zakat yang dikeluarkan dapat menolong orang-orang yang jiwanya atau kelangsungan hidupnya terancam di luar sana. Menjaga akal, karena dengan membayar zakat banyak orang yang tidak mampu untuk mengenyam pendidikan menjadi mampu untuk mengenyam pendidikan. Menjaga keturunan, sebab dengan membayar zakat nantinya akan memelihara kelangsungan hidup keturunan-keturunan orang yang menerimanya. Menjaga harta, sebab dengan membayar zakat, harta orang yang membayar zakat menjadi suci bersih sehingga mendapat barokah.

Dengan demikian jelaslah bahwa penurunan total MI pada BMI di tahun 2014 adalah disebabkan penurunan yang cukup signifikan pada rasio pendidikan $\left(R_{1}^{1}\right)$, rasio pelatihan $\left(R_{1}^{3}\right)$, rasio fair returns $\left(R_{2}^{1}\right)$, rasio bank's profit $\left(R_{3}^{1}\right)$, dan rasio invetasi pada sektor riil $\left(R_{3}^{3}\right)$. Selain faktor internal yang menyebabkan penurunan kinerja, faktor eksternal juga memegang peranan yang tidak kalah penting terhadap baik buruknya kinerja suatu perusahaan pada suatu periode. Terkait dengan hal tersebut, BMI juga merupakan sebuah entitas yang termasuk ke dalam subjek perekonomian pada sektor perbankan syariah di Indonesia yang juga tidak bisa luput dari pengaruh perekonomian pada suatu periode. Mengenai hal ini, diketahui bahwa menurunnya laju pertumbuhan sektor perbankan domestik pada tahun 2014 dibandingkan tahun sebelumnya sedikit banyak juga mempengaruhi industri perbankan, terutama pada melemahnya permintaan akan pembiayaan, sehingga hal ini ikut berdampak pada penurunan kinerja tahun 2014.

4.2 KINERJA BANK UMUM SYARIAH BERDASARKAN PENDEKATAN SCNP TAHUN 2010-2014

Tabel 7. Kinerja BUS Berdasarkan Pendekatan SCnP Tahun 2010-2014 


\begin{tabular}{|c|c|c|c|c|c|c|c|c|c|c|c|c|c|c|c|}
\hline \multirow{2}{*}{ Bank } & \multicolumn{3}{|c|}{2010} & \multicolumn{3}{|c|}{2011} & \multicolumn{3}{|c|}{2012} & \multicolumn{3}{|c|}{2013} & \multicolumn{3}{|c|}{2014} \\
\hline & SC & $\mathrm{P}$ & Q & $\mathrm{SC}$ & $\mathrm{P}$ & Q & SC & $\mathrm{P}$ & $\mathrm{Q}$ & $\mathrm{SC}$ & $\mathrm{P}$ & $Q$ & SC & $\mathrm{P}$ & Q \\
\hline BMI & 0.78469 & 0.11453 & URQ & 0.76743 & 0.10847 & URQ & 0.77806 & 0.16977 & URQ & 0.79717 & 0.17491 & URQ & 0.78195 & 0.01642 & LRQ \\
\hline BRIS & 0.73213 & 0.01343 & LRQ & 0.71963 & 0.01035 & LLQ & 0.72819 & 0.07333 & LLQ & 0.74417 & 0.07671 & LLQ & 0.74829 & 0.00365 & LRQ \\
\hline BSM & 0.75454 & 0.28350 & URQ & 0.73447 & 0.28242 & URQ & 0.73216 & 0.15969 & ULQ & 0.72162 & 0.10394 & ULQ & 0.71704 & 0.01137 & LRQ \\
\hline BMS & 0.67642 & 0.12236 & ULQ & 0.67037 & 0.07984 & LLQ & 0.66666 & 0.26124 & ULQ & 0.66675 & 0.13237 & ULQ & 0.66627 & 0.01530 & LLQ \\
\hline BPS & 0.81115 & $(0.19004)$ & LRQ & 0.77564 & 0.07946 & LRQ & 0.78586 & 0.11344 & LRQ & 0.77964 & 0.04326 & LRQ & 0.76628 & 0.07441 & URQ \\
\hline BSB & 0.70905 & 0.07032 & ULQ & 0.71661 & 0.06239 & LLQ & 0.72134 & 0.06803 & LLQ & 0.72724 & 0.06549 & LLQ & 0.44423 & 0.01478 & LLQ \\
\hline BCAS & 0.55446 & 0.04784 & LLQ & 0.71799 & 0.04641 & LLQ & 0.75920 & 0.04637 & LRQ & 0.78498 & 0.06185 & LRQ & 0.77678 & 0.05067 & URQ \\
\hline
\end{tabular}

Keterangan:

SC : Nilai Sharia Conformity (Kesesuaian Syariah)

P : Nilai Profitability (Profitabilitas)

Q : Quadrant (Posisi Bank Syariah Pada Grafik SCnP)

URQ : Upper Right Quadrant, yang berarti bahwa kesesuaian syariah tinggi dan profitabilitas tinggi.

LRQ : Lower Right Quadrant, yang berarti bahwa kesesuaian syariah tinggi tetapi profitabilitas rendah

ULQ : Upper Left Quadrant, yang berarti bahwa kesesuaian syariah rendah tetapi profitabilitas tinggi

LLQ : Lower Left Quadrant, yang berarti bahwa kesesuaian syariah rendah, dan profitabilitas rendah

Secara umum, dapat dilihat bahwa kondisi rata-rata bank umum syariah selama lima tahun sebagian besar terletak pada LLQ dan LRQ. Hal ini dibuktikan dari hasil perhitungan bahwa, dari 35 total titik penelitian menunjukkan posisi sebagai berikut: URQ 8 titik, LRQ 10 titik, ULQ 6 titik, dan LLQ 11 titik. Hal ini mengindikasikan bahwa mayoritas bank umum syariah di Indonesia memiliki kondisi profitabilitas cukup rendah dan nilai kesesuaian syariah yang masih cukup rendah, atau memiliki kondisi profitabilitas yang rendah, akan tetapi nilai kesesuaian syariahnya tinggi.

Berdasarkan tabel di atas, selama masa pengamatan lima tahun berturut-turut dapat terlihat bahwa Bank Muamalat Indonesia (BMI) adalah bank yang paling konsisten berada pada URQ. Hal ini berarti bahwa BMI adalah bank dengan kinerja terbaik berdasarkan ketaatan syariah dan profitabilitasnya.

Selain itu Bank Panin Syariah (BPS) yang secara konsisten berada di LRQ selama empat tahun berturut-turut namun pada akhirnya di tahun 2014 BPS berhasil menggeser posisinya ke kuadran URQ. Dari hasil perhitungan rasio-rasio SCnP diketahui bahwa BPS merupakan bank syariah yang mempunyai nilai sharia conformity yang sangat tinggi sehingga tidak pernah sekalipun BPS berada pada kuadran sebelah kiri, meskipun dilihat dari segi profitabilitasnya BPS masih perlu melakukan banyak perbaikan. 
Adapun Bank Syariah Mandiri yang merupakan bank syariah kedua berdiri di Indonesia, hanya dua kali berada di kuadran URQ, yakni pada tahun 2010 dan 2011. Di tahun 2012 dan 2013 BSM bergeser posisinya dari URQ ke ULQ, dan pada 2014 harus turun ke kuadran bawah LRQ. Dari hasil penelitian diketahui bahwa BSM selama empat tahun berturut-turut selalu berada pada kuadran atas (URQ/ULQ) dan tidak pernah berada pada kuadran bawah (LRQ/LLQ). Hal ini mengindikasikan bahwa BSM memiliki tingkat profitabilitas yang cukup tinggi di atas rata-rata pencapaian nilai profitabilitas bank syariah, namun masih perlu perbaikan dalam hal kesesuaian syariah..

Perkembangan perkembangan positif juga terlihat pada Bank Central Asia Syariah (BCAS). Pada tahun pengamatan pertama dan kedua BCAS menempati posisi LLQ, yang mengindikasikan bahwa BCAS merupakan bank syariah dengan tingkat kesesuaian syariah yang rendah dan tingkat profitabilitas yang rendah. Kemudian pada tahun pengamatan ketiga dan keempat posisi grafik BCAS bergeser ke LRQ, yang menandakan bahwa BCAS merupakan bank syariah yang memiliki nilai kesesuaian syariah yang tinggi akan tetapi profitabilitasnya masih rendah. Hal ini patut diapresiasi sebab dengan adanya pergerakan ke arah kanan, ini menandakan bahwa BCAS telah meningkatkan nilai kesesuaian syariahnya dibandingkan tahuntahun sebelumnya. Barulah kemudian pada tahun pengamatan terakhir BCAS berhasil menempati posisi di URQ, yang menandakan bahwa BCAS merupakan bank syariah yang memiliki nilai kesesuaian syariah yang tinggi dan juga profitabilitas yang tinggi.

Adapun gambaran SCnP untuk ketiga bank syariah lain, yakni Bank Syariah Bukopin (BSB), Bank Mega Syariah (BMS), dan Bank Rakyat Indonesia Syariah (BRIS) dari tahun ke tahun terbilang tidak cukup konsisten berada di suatu kuadran, melainkan selalu berpindah tempat tetapi masih sulit untuk menjangkau kuadran URQ. Ketiga bank syariah ini bahkan tergolong cenderung konsisten berada di kuadran sebelah kiri yang menandakan bahwa tingkat kesesuaian syariah pada ketiga bank syariah ini relatif masih rendah dibandingkan dengan rata-rata bank syariah lain. Selain tingkat kesesuaian syariahnya yang masih rendah, tingkat profitabilitas pada ketiga bank syariah ini pun juga relatif rendah. Hal ini dapat dibuktikan dari seringnya ketiga bank syariah ini memasuki kuadran LLQ. Jika ditelusuri lebih lanjut, penyebab rendahnya tingkat kesesuaian syariah pada bank-bank syariah tersebut adalah disebabkan rendahnya pembiayaan dengan akad bagi hasil yang merupakan salah satu komponen penting dari sharia conformity ini.

Penulis berpendapat bahwa hal ini berbanding lurus dengan tingkat profitabilitas ketiganya, dimana bank syariah yang rasio profit sharing-nya rendah maka pendapatan juga akan rendah. Terlihat dari beberapa contoh sebelumnya, bahwa bank syariah yang lebih banyak menyalurkan pembiayaan dengan sistem bagi hasil, pendapatannya lebih tinggi. Sejatinya jika ditelusuri lebih mendalam, pendapatan yang didapatkan dari bagi hasil akan lebih besar dibandingkan pendapatan yang diperoleh dari hasil jual beli maupun akad lainnya, meskipun dengan risiko yang cukup tinggi pula. Hal ini sesuai dengan aksioma manajemen keuangan high risk high return. 
Perhatian yang lebih khusus dan mendalam diperlukan oleh BSB yang terus konsisten di kuadran LLQ selama tahun 2011-2014. Sebab hal tersebut mengindikasikan bahwa BSB mempunyai tingkat kesesuaian syariah yang rendah dan juga profitabilitas yang rendah.

\subsection{KINERJA BANK UMUM SYARIAH BERDASARKAN PERINGKAT TERINGGI MAQASHID INDEKS DAN POSISI KUADRAN GRAFIK SCNP}

Berdasarkan pembahasan pada poin 4.2 dan 4.3 jika dirangkumkan dalam peringkat dari masing-masing MI dan posisi pada kuadran SCnP dari setiap bank umum syariah adalah sebagai berikut.

Tabel 8. Kinerja BUS Berdasarkan Peringkat Maqashid Indeks dan Posisi

\begin{tabular}{|l|c|l|c|l|c|c|c|c|c|c|}
\hline \multirow{2}{*}{ Bank } & \multicolumn{2}{|c|}{ Kuadran Grafik SCnP } \\
\cline { 2 - 12 } & Peringkat & $\begin{array}{c}\text { Posisi } \\
\text { Kuadran }\end{array}$ & Peringkat & $\begin{array}{c}\text { Posisi } \\
\text { Kuadran }\end{array}$ & Peringkat & $\begin{array}{c}\text { Posisi } \\
\text { Kuadran }\end{array}$ & Peringkat & $\begin{array}{c}\text { Posisi } \\
\text { Kuadran }\end{array}$ & Peringkat & $\begin{array}{c}\text { Posisi } \\
\text { Kuadran }\end{array}$ \\
\hline BMI & 1 & URQ & 2 & URQ & 2 & URQ & 1 & URQ & 3 & LRQ \\
\hline BRIS & 4 & LRQ & 5 & LLQ & 7 & LLQ & 4 & LLQ & 5 & LRQ \\
\hline BSM & 2 & URQ & 3 & URQ & 3 & ULQ & 6 & ULQ & 6 & LRQ \\
\hline BMS & 5 & ULQ & 7 & LLQ & 6 & ULQ & 7 & ULQ & 7 & LLQ \\
\hline BPS & 7 & LRQ & 1 & LRQ & 1 & LRQ & 5 & LRQ & 1 & URQ \\
\hline BSB & 3 & ULQ & 4 & LLQ & 4 & LLQ & 3 & LLQ & 4 & LLQ \\
\hline BCAS & 6 & LLQ & 6 & LLQ & 5 & LRQ & 2 & LRQ & 2 & URQ \\
\hline
\end{tabular}

$$
\text { Sumber: Data Diolah }
$$

Berdasarkan tabel di atas dapat terlihat bahwa dua bank syariah yang mempunyai nilai maqashid indeks tertinggi tidak selalu berada pada URQ yang berarti bahwa belum tentu bank syariah tersebut mempunyai kesesuaian syariah yang tinggi dan profitabilitas yang tinggi. Terbukti dari hasil penelitian bahwa bank syariah yang mempunyai nilai maqashid indeks tertinggi pertama, tiga kali berada pada URQ, dan dua kali berada di LRQ.

Perbedaan antara metode maqashid indeks dan SCnP ini juga diperjelas dengan hasil kuadran BPS di tahun 2011 dan 2012 yang selama dua kali mencapai peringkat tertinggi dengan pendekatan maqashid indeks, tetapi posisi kuadrannya berada pada posisi LRQ. Sedangkan BSM yang memiliki peringkat ketiga dengan pendekatan maqashid indeks, namun berada pada posisi URQ.

Oleh sebab itu, berdasarkan pembahasan di atas dapat diketahui bahwa bank syariah yang memiliki nilai maqashid indeks tertinggi belum tentu mendapat posisi di kuadran terbaik (URQ) pada model SCnP. Maka dengan demikian dapat disimpulkan bahwa model maqashid indeks dengan model SCnP keduanya merupakan metode yang berbeda dalam menilai tingkat kinerja bank syariah berdasarkan pendekatan syariah dan pendekatan konvensional -dalam hal ini profitabilitas-. Terlihat dari hasil penelitian bahwa bank-bank yang mendapat peringkat yang tertinggi pertama dengan mengunakan pendekatan maqashid indeks, namun tidak selalu berada pada kuadran URQ. Akan tetapi untuk bank syariah yang mempunyai peringkat pertama dan kedua dengan metode maqashid indeks, secara konsisten menunjukkan kemungkinan berada pada dua kuadran, yakni pada URQ atau LRQ. Ini berarti bahwa bank syariah yang mempunyai total MI peringkat 
pertama dan kedua belum tentu mempunyai tingkat profitabilitas yang tinggi, namun dapat dipastikan bahwa setiap bank syariah yang mempunyai total MI peringkat pertama dan kedua memiliki nilai kesesuaian syariah (sharia conformity) yang tinggi pula.

\section{SIMPULAN}

Pengukuran kinerja BUS di tahun 2010-2014 dengan menggunakan metode maqashid indeks menunjukkan hasil yang bervariasi dan mayoritas BUS di Indonesia menunjukkan kinerja yang fluktuatif dengan rentang indeks antara 0,16901-0,34297. Kinerja terbaik dicapai oleh BMI yang konsisten mempertahankan kinerja dengan total MI berada pada rentang 0,294030,34031 dan berhasil meraih peringkat 1 atau 2 selama empat tahun berturutturut. Hal ini merupakan sebuah kewajaran .mengingat BMI merupakan bank syariah yang pertama berdiri, namun hal itu ternyata tidak terjadi pada BSM yang merupkan bank syariah kedua berdiri. BSM sendiri tidak berhasil mencapai peringkat pertama atau kedua dengan pendekatan maqashid indeks. Adapun rentang perolehan maqashid indeks pada BSM hanya sebesar 0,26226-0,31354. Sedangkan lima BUS yang lainnya, yakni BRIS,BMS, BPS, BSB, dan BSB mendapatkan peringkat 1-7 dan mendapat perolehan nilai maqashid indeks antara 0,16901-0,34927. Selain itu dari hasil pengukuran diketahui bahwa pada tahun 2014 terjadi penurunan total MI secara besar-besaran pada seluruh bank kecuali BPS.

Adapun dengan menggunakan pendekatan SCnP, selama tahun 2010 sampai dengan 2014 menunjukkan persebaran ke dalam empat kuadran yang berbeda-beda setiap tahunnya, dan menunjuk BMI sebagai BUS berkinerja terbaik dengan pendekatan SCnP, hal ini disebabkan BMI merupakan BUS yang paling konsisten berada pada URQ. Adapun secara umum mayoritas BUS di Indonesia rata-rata berada pada posisi Lower Right Quadrant (LRQ) dan Lower Left Quadrant (LLQ). Hal ini berarti bahwa mayoritas BUS Indonesia terbagi menjadi dua kondisi: 1) BUS di Indonesia memiliki tingkat kesesuaian syariah tinggi tetapi tingkat profitabilitasnya rendah, 2) BUS di Indonesia memiliki tingkat kesesuaian syariah rendah, dan profitabilitasnya rendah.

Dengan menggunakan pendekatan SCnP, selama kurun waktu lima tahun dari tahun 2010 sampai dengan 2014 menunjukkan persebaran ke dalam empat kuadran yang berbeda-beda setiap tahunnya, dan menunjuk BMI sebagai BUS berkinerja terbaik dengan pendekatan SCnP, hal ini disebabkan BMI merupakan BUS yang paling konsisten berada pada URQ. Adapun secara umum mayoritas BUS di Indonesia rata-rata berada pada posisi Lower Right Quadrant (LRQ) dan Lower Left Quadrant (LLQ). Hal ini berarti bahwa mayoritas bank umum syariah Indonesia terbagi menjadi dua kondisi: 1) BUS di Indonesia memiliki tingkat kesesuaian syariah tinggi tetapi tingkat profitabilitasnya rendah, 2) BUS di Indonesia memiliki tingkat kesesuaian syariah rendah, dan profitabilitasnya rendah. 


\section{DAFTAR PUSTAKA}

Antonio, M. S., Sanrego, Y. D., \& Taufiq, M. (2012). An Analysis of Islamic Banking Performance: Maqashid Index Implementation in Indonesia and Jordania. Journal of Islamic Finance, 1(1).

Auda, J. (2008). Maqasid Al-Shariah an Introductory Guide. IIIT.

Badreldin, A. M. (2009). Measuring The Performance of Islamic Banks by Adapting Conventional Ratios. German University in Cairo Working Paper Series No.16, 1-26.

Bank Panin Syariah. (2012). Laporan Tahunan Tahun 2011. Jakarta: PT. Bank Panin Syariah.

Bank Syariah Mandiri. (2015). Laporan Keberlanjutan (Sustainability) Bank Syariah Mandiri 2014. Jakarta: PT. Bank Syariah Mandiri.

Bank Syariah Mandiri. (2015). Laporan Tahunan PT. Bank Syariah Mandiri 2014. Jakarta: PT. Bank Syariah Mandiri.

Departemen Agama RI. Al-Quran Tafsir Per Kata Tajwid Kode Angka. Jakarta: Kalim.

Ernst and Young. (2015). World Islamic Banking Competitiveness 2013-14. Ernst and Young.

Erol, C., F. Baklaci, H., Aydoğan, B., \& Tunç, G. (2014). Performance comparison of Islamic (participation) banks and commercial banks in Turkish banking sector. EuroMed Journal of Business, 9(2), 114-128.

Hamidi, J., Hamidah, S., Sukarmi, Sihabuddin, Hendrawati, L., \& Kusumaningrum, A. (2006). Persepsi dan Sikap Masyarakat Santri Jawa Timur Terhadap Bank Syariah. Perbankan dan Stabilitas , 1-16.

Ismail, F., Shabri Abd. Majid, M., \& Rahim, R. A. (2013). Efficiency of Islamic and conventional banks in Malaysia. Journal of Financial Reporting and Accounting, 11(1), 92-107.

Kamali, M. H. (2008). Maqasid al-Shari'ah Made Simple. The International Institute of Islamic Thoughts , 1-7.

Kuppusamy, M., Saleh, A. S., \& Samudhram, A. (2010). Measurement of Islamic banks performance using a shariah conformity and profitability model. Review of Islamic Economics, 13(2), 35-48.

Mustafa Omar, M. (2015). Developing Islamic banking performance measures based on Maqasid al-shari'ah framework: cases of 24 selected banks'. Journal of Islamic Monetary Economics and Finance (JIMF), l(1), 55-77. 
Mohammed, M. O., Razak, D. A., \& Taib, F. M. (2008). The Performance Measures of Islamic Banking Based on the Maqasid Framework. 1-17.

Moin, M. S. (2008). Perfomance of Islamic Banking and Conventional Banking in Pakistan: A Comparative Study. Master Degree Project in Finance Advance Level-University of Skovde , 1-48.

Mu'allim, A. (2003). Persepsi Masyarakat Terhadap Lembaga Keuangan Syariah. Al-Mawarid, X, 17-31.

Ohio University Library. (1997, November 4). Ohio Library. Dipetik Oktober 24, 2015, dari Ohio Library: http://www.library.ohiou.edu/indopubs/1997/11/04/0014.html

OJK. (2015, Juni). Website OJK. Dipetik September 16, 2015, dari Statistik Perbankan Syariah: http://www.ojk.go.id/data-statistik-perbankansyariah

Azhar Rosly, S., \& Afandi Abu Bakar, M. (2003). Performance of Islamic and mainstream banks in Malaysia. International Journal of Social Economics, 30(12), 1249-1265.

Suhada, S., \& Pramono, S. (2017). Analisis Kinerja Perbankan Syariah Di Indonesia Dengan Pendekatan Maqoshid Indeks (Periode 20092011). JURNAL AKUNTANSI DAN KEUANGAN ISLAM, 2(1), 5-34.

Usman, H. (2015). Customers Trust on Islamic Banks in Indonesia. Journal of Asian Finance, Economics, and Business , 2 (1), 5-13.

Widigdo, A. M., Marimin, \& Fahmi, I. (2016, Januari 28). Iqtishodia. Seberapa Syariah Bank Syariah di Indonesia, hal. 1-3.

Zahrah, M. A. (2011). Ushul Fiqh. (S. Ma'shum, S. Bashir, M. Rahmat, H. Ahmad, H. Rasyid, A. Zawawi, et al., Penerj.) Jakarta: PT. Pustaka Firdaus. 